Revista Bioética

\title{
ATUALIZAÇÃO
}

\section{The duty to treat in the context of the Covid-19 pandemic}

Oana-Maria Isailă ${ }^{1}$, Sorin Hostiuc ${ }^{1}$

1. Faculty of Dental Medicine, Department of Legal Medicine and Bioethics, Carol Davila University of Medicine and Pharmacy, Bucharest, Romania.

\begin{abstract}
The duty to treat has been at the center of the moral and public debate surrounding the physician-patient relationship, especially in epidemics. The topic of discussion may be the physician who "fights" (the "hero physician"), the contaminated professional, the doctor who refuses to treat or the resigning physician. This may increase potential conflicts between the physicians' individual values and those of their patients, conflicts that can have personal and social consequences. Doctors implicitly assume that treating patients may generate risks for his/her own well-being, but none should accept risks related to insufficient protective equipment or inappropriate protocols, or other external causes that unjustifiably increase them. Everybody involved in healthcare has the duty to minimize the risks imposed on the patient; otherwise not only physicians are at risk, but also patients and society, which could receive less healthcare or even develop other diseases.

Keywords: Coronavirus infections. Pandemics. Risk. Beneficence.
\end{abstract}

\section{Resumo}

\section{O dever de tratar no contexto da pandemia de covid-19}

O dever de tratar está no centro do debate moral e público sobre a relação médico-paciente, especialmente em epidemias. O tópico da discussão pode ser o médico que "luta" (o "médico herói"), o profissional contaminado, aquele que se recusa a tratar ou se demitiu. Este aumento de potenciais conflitos entre os valores individuais do profissional e os do paciente podem ter consequências pessoais e sociais. Qualquer médico aceita, implicitamente, que o tratamento do enfermo pode gerar riscos para o próprio bem-estar, mas nenhum profissional deve aceitar riscos causados por equipamento de proteção insuficiente ou protocolos inadequados ou outras causas externas que os aumentem sem motivos justificáveis. Todos os envolvidos no cuidado à saúde devem minimizar os riscos impostos ao enfermo; caso contrário, não apenas o profissional está em risco, mas também os pacientes e a sociedade, que podem receber menos cuidados de saúde ou ainda desenvolver outras doenças.

Palavras-chave: Infecções por coronavirus. Pandemias. Risco. Beneficência.

\section{Resumen}

\section{El deber de tratar en el contexto de la pandemia de covid-19}

El deber de tratar está en el centro del debate moral y público que rodea la relación médico-paciente, especialmente en epidemias. El tema de discusión puede ser el médico que "lucha" (el "médico héroe"), el médico contaminado, el médico que se niega a tratar o el médico que renuncia. Este aumento de posi-bles conflictos entre los valores del profesional y del paciente puede tener consecuencias personales y sociales. Todo médico acepta, implícitamente, que su trabajo puede poner en riesgo su bienestar, pero ningún profisional debe aceptar los riesgos causados por un equipo de protección insuficiente, por pro-tocolos inapropiados $u$ otras causas externas. Todos los involucrados tienen el deber de minimizar los riesgos al paciente, ya que de lo contrario no solo el médico está en riesgo, sino también toda la socie-dad, visto que los pacientes pueden recibir menos atención médica o desarrollar más enfermedades.

Palabras clave: Infecciones por coronavirus. Pandemias. Riesgo. Beneficencia.

The authors declare no conflict of interest. 
The duty to treat has been at the center of the moral and public debate surrounding the physicianpatient relationship in numerous epidemics, ever since the Ancient Greece. According to Langholf, in the text Of the epidemics Hippocrates states:

With regard to the dangers of these cases, one must always attend to the seasonable concoction of all the evacuations, and to the favorable and critical abscesses. The concoctions indicate a speedy crisis and recovery of health; crude and undigested evacuations, and those which are converted into bad abscesses, indicate either want of crisis, or pains, or prolongation of the disease, or death, or relapses; which of these it is to be must be determined from other circumstances. The physician must be able to tell the antecedents, know the present, and foretell the future - must mediate these things, and have two special objects in view with regard to disease, namely, to do good or to do no harm. The art consists in three things - the disease, the patient, and the physician. The physician is the servant of the art, and the patient must combat the disease along with the physician ${ }^{1}$.

During epidemics, there have been instances in which physicians have fled the cities, leaving patients unattended. This has been cited even for titans of medicine, such as Galen, who fled Rome during the Antonine plague, or Sydenham, who left London in the 1645-1646 epidemic ${ }^{2-4}$. In the 14th and 15th centuries, physicians left Venice in order not to get infected with the Black Death plague ${ }^{4-6}$. During the yellow fever outbreak in Philadelphia, in 1793 , some physicians ran away from the city ${ }^{4}$. In the Romanian Principalities, in 1813, during a bubonic plague, the ruler Caragea withheld the salary of all Bucharest physicians because many were fleeing the city: I hath ordained wages to physicians of this settlement, not for engagement alone, but to show with deeds and not astray from the settlement when called upon for sores and sickness (...) we command thee, that henceforth when each one of them went amiss from this settlement [physicians Constantin Caracas and Constantin Filipescu], to be destitute of wage ${ }^{7}$. Nevertheless, these are usually exceptions to the rule - normally the physicians remained in the pest hole for various reasons, be they material, religious or for fear of being stigmatized, but one of them has also been the sense of duty towards the patient ${ }^{4,5}$.

Later, the American Medical Association (AMA) ${ }^{8}$, founded in Philadelphia in 1847, drafted a code of ethics through which they clarified the duties of physicians in epidemiological contexts. In $\S 1$ of article I of its Chapter 111, this code states that:
As good citizens, it is the duty of physicians to be ever vigilant for the welfare of the community, and to bear their part in sustaining its institutions and burdens: they should also be ever ready to give counsel to the public in relation to matters especially appertaining to their profession, as on subjects of medical police, public hygiene, and legal medicine. It is their province to enlighten the public in regard to quarantine regulations, - the location, arrangement, and dietaries of hospitals, asylums, schools, prisons, and similar institutions, - in relation to the medical police of towns, as drainage, ventilation, \&c., and in regard to measures for the prevention of epidemic and contagious diseases; and when pestilence prevails, it is their duty to face the danger, and to continue their labours for the alleviation of the suffering, even at the jeopardy of their own lives ${ }^{8}$.

Similarly, in Europe, some authors have emphasized the rights and duties of doctors in times of epidemics. For example, Max Simon ${ }^{2}$, in his Déontologie médicale, has a very significant chapter in this regard, entitled "Devoirs des médecins dans les épidémies, et les maladies contagieuses," in which he discusses the duties of the physicians in epidemics. Albert Moll, in his Ärzlichte Ethik, also says that when they (n.n. doctors) expose themselves to death in these cases, the doctors do nothing more than their duty. But one should not forget that the doctor also has relatives who lose their loved one when he dies ${ }^{9}$. Even if these books or codes of ethics provide specific recommendations for physicians, they are not mandatory, and doctors often need to act according to their own morals and beliefs ${ }^{5}$, based on virtues such as empathy, altruism, compassion, justice and fidelity.

As a general rule, physicians have treated patients throughout all the pandemics (with rare exceptions), including the Spanish Flu of 1918, and patients in the epicenter of tuberculosis outbreaks ${ }^{5}$. Debates on the duty to treat have also appeared in the 1980s during the Aids crisis, as well as in 2003 during the Sars epidemic ${ }^{10}$ and the Ebola outbreak of 2014-2016 ${ }^{11}$.

On March 11, 2020, the World Health Organization (WHO) ${ }^{12}$ declared coronavirus disease 2019 (Covid-19) a pandemic - the spreading of a disease on a global scale -, the last one after the H1N1 outbreak in 2009. In a pandemic, especially one as extended as the one caused by Covid-19, healthcare systems are severely challenged at a global level, resources are scarce, and medical personnel are overstrained. One of the recurring moral issues that appear in these circumstances is 
the duty of the physicians to treat patients with this disease, and the purpose of this article is to evaluate this duty from an ethical perspective and to identify its range and limits.

\section{The duty to treat or the duty to provide medical care}

The duty to provide medical care is doubled by diligence - the exercise of duty with perseverance to fulfill moral obligation with no regard to the reward. There are four levels: duty as an intrinsic moral obligation, as an answer to the given trust, as a professional behavioral norm, and as imposed by the work code ${ }^{13}$. As a general rule, the commitment to treat appears whenever a physician-patient relationship has been established, either with the explicit agreement of both parties or whenever the doctor has the duty to intervene, even without the agreement of the patient (who may be comatose, without insight, a small child etc.). Most codes of ethics emphasize four main general duties/rights of the physician within this contractual relationship: toward the patient, society, colleagues, and him/herself.

During a pandemic, or in any high-risk situation, an additional duty is described, which overlaps all four, namely the duty to minimize contamination risks ${ }^{14}$. Respecting this duty should be an absolute priority for the physician and the healthcare system because a sickened doctor will not only generate harm to himself but also to other colleagues (whom he may also infect), the patients and society (as she/he could spread the disease, but also because he will not be able to work anymore, thereby increasing the strain on other healthcare workers).

Malm and collaborators ${ }^{15}$ argued this duty to treat in infectious contexts is justified by five elements. The first one is express consent - the doctors sign a contract with the medical unit to treat patients according to his/her specialty. The second is implied consent - the profession has always been associated with health-related risks for the practitioners, and therefore anyone, when agreeing to be part of this guild, also agrees to these potential risks, which became implicit.

The third is special instruction - physicians receive, through medical school and residency, special training to minimize the risks associated with the medical practice. An infectious disease specialist, for instance, has special knowledge and specific protective equipment to work with contagious patients, which another specialist (such as a general practitioner) does not have, and therefore he/she will manage the disease more efficiently and with less additional risks.

The fourth is reciprocity - the physician has a special social status and certain additional benefits related to the profession. This includes the special training, which can be publicly funded and is done on patients who agree to be treated by physiciansin-training for them to learn how to treat others. Thus, doctors are also indebted to society and must help and act according to his/her status and the societal expectations.

The last element is represented by oaths and professional codes. They usually have a general character, and only present some general codes of conduct in epidemics ${ }^{15}$. However, these guidelines should be respected and the base for more targeted moral codes, developed specifically for epidemic outbreaks.

\section{Limits of the duty to treat}

The practice of medicine involves assumed risks but also situations that, managed inadequately, are a threat for the physician and for society. During the Covid-19 pandemic, as with any pandemic, there is a contamination risk for the medical staff, a risk that, in the absence of adequate protective equipment and agreement of the patient, may have severe repercussions on other persons or the society at large. According to the WHO, health workers are at the front line of the Covid-19 outbreak response and as such are exposed to hazards that put them at risk of infection. Hazards include pathogen exposure, long working hours, psychological distress, fatigue, occupational burnout, stigma, and physical and psychological violence ${ }^{16}$.

If infected, the physician is not only the one treating the patient, but also a vector, transmitting the disease to others ${ }^{17}$. This fact, together with his/her removal from the front line, once he/she is rendered unable to work, will increase the strain on an already weakened medical system.

According to WHO's provisions concerning the rights, roles and responsibilities in healthcare, medical staffs have the right to adopt protection and prevention measures, utilize information and training related to safety in the workplace, perfecting courses in preventing and controlling infections, and use protective equipment (masks, gloves, protective eyewear, robes, disinfecting products) in enough quantities for those who are tending to patients 
suspected and/or confirmed with Covid-19. They also have the right to adjust instruments to evaluate, select, test and treat patients, to personal safety, to remain at their residence when they are sick, and to retreat from a professional situation when it poses an imminent and severe danger to their life and health ${ }^{16}$.

To protect the parties involved in the pandemic, the WHO released a guide on the rational use of personal protective equipment (PPE) for Covid-19, considering that the current global stockpile of PPE is insufficient, particularly for medical masks and respirators, and the supply of gowns, goggles and face shields is now insufficient to satisfy the global demand. Surging global demand - driven not only by the number of Covid-19 cases but also by misinformation, panic buying and stockpiling - has resulted in further shortages of PPE globally. The capacity to expand PPE production is limited, and the current demand for respirators and masks cannot be met, especially if widespread inappropriate use of PPE continues ${ }^{18}$.

The AMA, in its ethical code, states that physicians should balance immediate benefits to individual patients with ability to care for patients in the future ${ }^{19}$. Therefore, to be beneficial to the patient and society, the duty to treat in the context of a pandemic must be based on a proper riskbenefit analysis. At a personal and societal level, this assessment should consider not only the prospective consequences of various medical acts, including those resulting from the indiscriminate usage of this "duty to treat," which should be understood, as Hippocrates said, from the perspective of the patient, physician, and the disease ${ }^{20}$.

The principles of bioethics are essential in a pandemic, but they become multifaceted. The principle of beneficence leads to the duty to treat patients, of helping colleagues and society, and is conditioned by the duty of being correctly informed about preventive measures, treatments, and management of disease with all its possible clinical manifestations. The principle of non-maleficence leads to the duty of minimizing risks for the patients, colleagues and society ${ }^{14}$. This implies, for example, using adequate protective gear, isolation in case of contamination, and following therapeutic standards. Doctors must remain calm and use all available measures to protect their health and of those around them ${ }^{21}$.

Sometimes, the duty not to treat becomes morally relevant - a diseased physician may do more harm than good, breaching the principle of nonmaleficence, by trying to respect his duty to treat. Even if this is the correct approach from a moral and medical perspective, it may cause decreased public trust toward the medical profession, or even a medical stigma ${ }^{14}$, as the society sees only the end-results (non-treatment), and not the morally relevant reasoning behind this approach.

Respecting the principle of justice is delicate in the actual context of the pandemic, as resources on a global scale are limited. The doctor has the duty to respect the rights of everyone involved as much as the possibilities allow, based on an adequate triage and medical prioritization. Furthermore, for a treatment to be effective during a pandemic, a good coordination between the state institutions to stop the spreading of the disease is required, and patients must be compliant.

Measures such as isolation and quarantine have shown their effectiveness since the earliest of times. In some situations, the patient does not fully understand or denies the disease and its social repercussions, relying on sociocultural aspects from before the pandemic. Patients' virtues - honesty, compliance, tolerance and trust 22 - can be key elements to their own good as well as for the good of society in the context of limited resources.

\section{The duty to provide medical care versus implied risks}

A physician has the duty to provide medical care/to treat even when this implies the risk of contamination. Until April 2020, over 300 deaths had been reported among physicians worldwide as a result of Covid-19 infection ${ }^{23}$, and many more cases of infected health professionals. Sporadically, there have been reports in the media of some doctors resigning or refusing to treat, as well as their complaints concerning the lack of protective equipment, which in theory is mandatory but practically nonexistent ${ }^{24}$.

In the absence of adequate protection, is the risk of infection acceptable? Is there a middle ground between heroism - which in this situation is equivalent to respecting the duty to treat - and breaching this duty when resources are scarce? When protective equipment is inadequate or sometimes nonexistent, this duty becomes questionable, since respecting it would lead to an opposite effect to all parties involved during this infection.

Physicians need to work with health care institutions, regulatory bodies and the public to ensure that those working during a pandemic feel safe and willing to exercise the profession ${ }^{25}$. They 
must clearly and transparently state the conditions that have led to the decisions of not respecting the duty to treat, to maintain addressability, trust and compliance of the patients ${ }^{26}$.

\section{Final considerations}

Respecting the rights and interests of all parties involved in an epidemic is essential. The duty of a physician to treat a patient, even if it implies the risk of contamination, is conditioned by the duty of protecting him/herself as well as the patient and society, according to adequate instruction and information. The limits of the duty to treat or to provide medical care correctly, as it is understood by the physician, should not lead to the refusal to treat a sick person in unjustified situations. The duty to treat, rightfully understood by the patient as well as by society, must not be a means for intimidation and depersonalizing a professional. The medical staff also has the duty to protect itself when providing medical care, and they may refuse to work if they do not have the appropriate conditions.

\section{References}

1. Langholf V. Medical theories in Hippocrates: early texts and the "Epidemics". Berlim: Walter de Gruyter; 2011. p. 18. DOI: 10.1515/9783110847598

2. Simon M. Déontologie médicale, ou des devoirs et des droits des médecins, dans l'état actuel de la civilisation. Londres: JB Baillière; 1845.

3. Porter R. The greatest benefit to mankind: a medical history of humanity. Londres: W. W. Norton; 1999.

4. Schwartz AR. Doubtful duty: physicians' legal obligation to treat during an epidemic. Stanford Law Rev [Internet]. 2007 [acesso 10 jun 2020];60(2):657-94. Disponível: https://bit.ly/2WrtiMd

5. Zuger A, Miles SH. Physicians, aids, and occupational risk: historic traditions and ethical obligations. Jama [Internet]. 1987 [acesso 1ㅇ jun 2020];258(14):1924-8. DOI: 10.1001/ jama.1987.03400140086030

6. Byrne JP. The black death [Internet]. Londres: Greenwood; 2004 [acesso 10 jun 2020]. Disponível: https://bit.ly/32qgute

7. Urechia V. Istoria româniloru. Bucareste: Carol Gübl; 1891. p. 541. Tradução livre.

8. American Medical Association. Code of medical ethics of the American Medical Association [Internet]. Chicago: American Medical Association Press; 1847 [acesso 10 jun 2020]. Disponível: https://bit.ly/2Dr3dpW

9. Moll A. Ärztliche Ethik: die Pflichten des Arztes in allen Beziehungen seiner Thätigkeit. Erlangen: Enke; 1902. p. 562. Tradução livre.

10. Ruderman C, Tracy CS, Bensimon CM, Bernstein M, Hawryluck L, Shaul RZ, Upshur REG. On pandemics and the duty to care: whose duty? Who cares? BMC Med Ethics [Internet]. 2006 [acesso 10 jun 2020];7:5. DOI: 10.1186/1472-6939-7-5

11. Kpanake L, Tonguino TK, Sorum PC, Mullet E. Duty to provide care to Ebola patients: the perspectives of Guinean lay people and healthcare providers. J Med Ethics [Internet]. 2018 [acesso 10 jun 2020];44:599-605. DOI: 10.1136/medethics-2017-104479

12. World Health Organization. WHO Director-General's opening remarks at the media briefing on Covid-19: 11 March 2020 [Internet]. 11 mar 2020 [acesso 10 jun 2020]. Disponível: https://bit.ly/3fzPHyo

13. Curcă GC. Elemente de etică medicală: norme de etică în practica medicală: despr principiile bioeticii. Cluj-Napoca: Casa Cărţii de Ştiinţă; 2013.

14. Simonds AK, Sokol DK. Lives on the line? Ethics and practicalities of duty of care in pandemics and disasters. Eur Respir J [Internet]. 2009 [acesso 10 jun 2020];34:303-9. DOI: 10.1183/09031936.00041609

15. Malm H, May T, Francis LP, Omer SB, Salmon DA, Hood R. Ethics, pandemics, and the duty to treat. Am J Bioeth [Internet]. 2008 [acesso 10 jun 2020];8(8):4-19. DOI: 10.1080/15265160802317974

16. World Health Organization. Coronavirus disease (Covid-19) outbreak: rights, roles and responsibilities of health workers, including key considerations for occupational safety and health [Internet]. 18 mar 2020 [acesso 1ㅇ jun 2020]. Disponível: https://bit.ly/2OB1wbM

17. Mayo Clinic. Coronavirus disease 2019 (Covid-19) [Internet]. 2020 [acesso 10 jun 2020]. Disponível: https://mayocl.in/2ZCHWCj

18. World Health Organization. Rational use of personal protective equipment for coronavirus disease (Covid-19) and considerations during severe shortages [Internet]. 6 abr 2020 [acesso 10 jun 2020]. p. 8. Disponível: https://bit.ly/2DTaij9

19. AMA Council on Ethical and Judicial Affairs. AMA Code of Medical Ethics' opinion on physician duty to treat. AMA J Ethics [Internet]. 2010 [acesso 10 jun 2020];12(6):459. Disponível: https://bit.ly/2B7EeXI

20. Langholf V. Op. cit. 
21. Hostiuc S, Buda O, editores. The age of informed consent: a european history [Internet]. Newcastle upon Tyne: Cambridge Scholars Publishing; 2019 [acesso 1ํ jun 2020]. Disponível: https://bit.ly/3h6gB12

22. Pellegrino ED, Thomasma DC. For the patient's good: the restoration of beneficence in health care. Nova York: Oxford University Press; 1988.

23. Medscape. In memoriam: healthcare workers who have died of Covid-19 [Internet]. 1 o abr 2020 [acesso 10 jun 2020]. Disponível: https://wb.md/32tihgY

24. Petkova M. Dozens of Bulgarian doctors resign amid Covid-19 crisis. Al Jazeera News [Internet]. 18 mar 2020 [acesso 10 jun 2020]. Disponível: https://bit.ly/30dF3Xm

25. Davies CE, Shaul RZ. Physicians' legal duty of care and legal right to refuse to work during a pandemic. CMAJ [Internet]. 2009 [acesso 10 jun 2020]. DOI: 10.1503/cmaj.091628

26. British Columbia Ministry of Health. Covid-19 ethics analysis: what is the ethical duty of health care workers to provide care during Covid-19 pandemic? [Internet]. 28 mar 2020 [acesso 10 jun 2020]. Disponível: https://bit.ly/3jhla9M

\section{Participation of the authors}

The authors conceived, planned and wrote the article together.

\section{Correspondence}

Oana-Maria Isailă - Vitan Bârzești, 9-11. Bucareste, Romênia.

Oana-Maria Isailă - PhD - oana_maria.isaila@yahoo.com

(iD) 0000-0001-9370-6982

Sorin Hostiuc - PhD - sorin.hostiuc@umfcd.ro

(iD) $0000-0003-4130-9402$

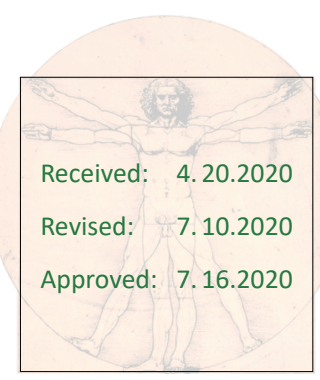

